\title{
Dendrimer-Functionalized Multi-walled Carbon Nanotubes Exhibit Dual-Phase Regulation to Exposed Murine Embryonic Stem Cells
}

Daxiang Cui ${ }^{1,2} *$, Hong Zhang ${ }^{1}$, Zheng Wang ${ }^{2}$, Lili Feng ${ }^{2}$, Jing Ruan ${ }^{2}$, Asahi. Toru ${ }^{1}$, Osaka Tetsuya ${ }^{1}$

${ }^{1}$ Consolidated Research Institute for Advanced Science and Medical Care, Waseda university, 513 Wasedatsurumaki-cho, Shinjuku-ku, Tokyo 1620041, Japan

${ }^{2}$ Department of Bio-Nano-Science and Engineeriniocg, National Key Laboratory of Nano/Micro Fabrication Technology, Key Laboratory for Thin Film and Microfabrication of Ministry of Education, Institute of Micro-Nano Science and Technology, Shanghai JiaoTong University, 800 Dongchuan Road, Shanghai 200240, People's Republic of China

* Corresponding author: dxcui@sjtu.edu.cn (Daxiang Cui)

\begin{abstract}
Herein we reported the effects of generation 5 polyamidoamine dendrimer-functionalized fluorescent multi-walled carbon nanotubes(dMNTs) on mice embryonic stem cell line CCE. The dMNTs were prepared and characterized, and incubated with murine embryonic stem cell CCE cells(ES) for 1 to 5 day. These ES cells were observed by fluorescent microscopy, and were analyzed by flow cytometer and MTT. Results showed that the dendrimerfunctionalized fluorescent multi-walled carbon nanotubes were successfully synthesized, could enter into ES cells quickly, more than $20 \mu \mathrm{g} \mathrm{m}^{-1}$ dose caused ES cells became smaller and smaller as the incubation time increased, and inhibited cell growth in dose- and time-dependent means, less than $5 \mu \mathrm{g} \mathrm{mL}^{-1}$ dose improves ES differentiation. These results demonstrate that dMNTs are toxic to ES cells at large dose, can induce ES cells' differentiation at lower dose. The prepared dMNTs may be a good dual-phase regulation reagent to exposed ES cells, and have potential applications in research and development of ES cells.
\end{abstract}

Keywords: Nembryonic stem cells, Dendrimer, Multi-walled carbon nnaotubes, Proliferation, Differentiation

Citation: D. Cui, et al. Dendrimer-Functionalized Multi-walled Carbon Nanotubes Exhibit Dual-Phase Regulation to Exposed Murine Embryonic Stem Cells . Nano Biomed. Eng. 2011, 3(4), 227-231. DOI: 10.5101/nbe.v3i4.p227-231.

\section{Introduction}

Since embryonic stem cells(ES) were first isolated in the 1980s [1], the pluripotential nature of ES cells to differentiate into cell types of all three primary germ lineages display charming prospect for disease therapy [2-4]. ES cells' study has been being made great progress. Although there exist many opportunities in study and development of stem cells today, there exist still great challenges in the technologies of generating progenitor cells with in-vivo reconstitution function and understanding the mechanisms of development and differentiation of ES cells, therefore it is very necessary to explore and develop new technologies.

Carbon nanotubes, as a class of stiff, stable and hollow nanomaterials with many unique properties such as mechanical, physical and chemical properties, have been being explored applications in medical chemistry and biomedical engineering [5,6]. Carbon nanotubes including both single-walled and multi-walled carbon nanotubes, have been actively functionalized with different biological molecules and investigated as possible multifunctional biological transporters $[7,8]$. Previous reports show that single-walled carbon nanotubes can take antisense oligonucleotides [9], plasmid DNA [10], siRNA [11], and peptides [12] across cell membrane, and also can be used as near-infrared agents for selective cancer cell imaging and therapy $[13,14]$.

Dendrimers are a novel special class of organic molecules: they can take different functional groups through a series of chemical modifications, and their interior cavities can serve as storage areas for a lot of genes or drugs $[15,16]$. Dendrimers may be a good nonviral delivery vector because it has the advantages of safety, simplicity of use, and ease of mass production compared with viral vectors that are inherently risky 
for clinical use $[17,18]$. Polyamidoamine (PAMAM) dendrimer-modified magnetic nanoparticles can markedly enhance the delivery efficiency for antisense oligonucleotides [19], dendrimer-modified single walled carbon nanotubes can reduce cytotoxicity and enhance the cellular uptake of the nanoparticles [20-24], and can release slowly those absorbed genes for two weeks.

Here we fully use advantages of multi-walled carbon nanotubes and polyamidoamine dendrimer, firstly investigated the effects of generation 5 dendrimerfunctionalized multi-walled carbon nanotubes on mouse ES CCE cells with the aim of developing new method of regulating development and differentiation of ES cells based on nanomaterials.

\section{Experimental Section}

\subsection{Materials source}

Ethylenediamine and methylacrylate were purchased from Aldrich Chemical Company. Multi-walled carbon nanotubes(MCNTs) were obtained from Shenzhen Nanoport Company (Shenzhen, China). Murine ES CCE cell line was kept in consolidated research institute for advanced science and medical care, Waseday university. RPMI 1640 medium containing 10\% fetal calf serum was from Gibco Company. 3-(4,5-Dimethyl-2-thiazolyl)-2,5diphenyl-2H-tetrazolium bromide (MTT) was obtained from Dojin Laboratories (Kumamoto, Japan). Rabbit antimouse monoclonal antibody against fibronectin, $\beta$-actin antibody, and horseradish peroxidase(HRP)-conjugated goat anti-rabbit secondary antibody were from Invitrogen Co. Enhanced chemiluminescence kits were from Amersham Company ( Germany).

\subsection{Synthesis of dendrimer-functionalized multi- walled carbon nanotubes}

MNTs were added to $60 \%$ aqueous nitric acids. The mixture was placed in an ultrasonic bath for $60 \mathrm{~min}$ and then stirred for $24 \mathrm{~h}$ while being boiled under reflux. The mixture was then vacuum-filtered through a $0.22 \mu \mathrm{m}$ Millipore polycarbonate membrane and subsequently washed with distilled water until the $\mathrm{pH}$ of the filtrate was ca. 7. The filtered solid was dried under vacuum for 24 $\mathrm{h}$ at $70^{\circ} \mathrm{C}$, yielding MWNT-COOH. The dried MWNT$\mathrm{COOH}$ was suspended in $\mathrm{SOCl}_{2}$ and stirred for $48 \mathrm{~h}$ at $70^{\circ} \mathrm{C}$. The solution was filtered, washed with anhydrous $\mathrm{THF}$, and dried under vacuum at room temperature for $48 \mathrm{~h}$, generating MWNT-COCl. The dried MWNT$\mathrm{COCl}$ was mixed with ethylenediamine at a ratio of $1: 2$ and stirred for $48 \mathrm{~h}$ at $80^{\circ} \mathrm{C}$. The resulting solid was separated by vacuum-filtration using a $0.22 \mu \mathrm{m}$ Millipore polycarbonate membrane filter and subsequently washed with water, generating MWNT- $\mathrm{NH}_{2} .50 \mathrm{mg}$ dried CNT$\mathrm{NH}_{2}$ was dispersed in $20 \mathrm{ml}$ of $20 \%$ methylacrylate aqueous solution. The suspension was immersed in a sonicating water bath at $25^{\circ} \mathrm{C}$ for $3 \mathrm{~h}$. The particles were then washed with water. After washing, $20 \mathrm{ml}$ of a 1:1 methanol-ethylenediamine solution was then added to the complex, and the mixture was allowed to proceed under the same conditions. Stepwise growth using methylacrylate and ethylenediamine was repeated until the No.5 generation of dendrimer-modified MNTs was achieved. The CdTe nanocrystals with $\mathrm{COOH}$ group mixed with dMNTs, the resultant fluorescent dMNTs were washed 3 times with $25 \mathrm{ml}$ water for usage $[25,26]$.

\subsection{Characterization of dendrimer-modified multi- walled carbon nanotubes}

High-resolution transmission electron microscopy (HR-TEM, Hitachi H-700H, Hitachi, Japan) was used to confirm the size of the carbon nanotubes and observe the dendrimer-coating layer on the MNTs. Zeta potential was measured with Zetasizer 2000 instruments (Malvern Co., England). Atomic force microscopy (AFM) imaging was performed by a Nanoscope III (Digital Instruments/Veeco Metrology Group, United States). AFM images were
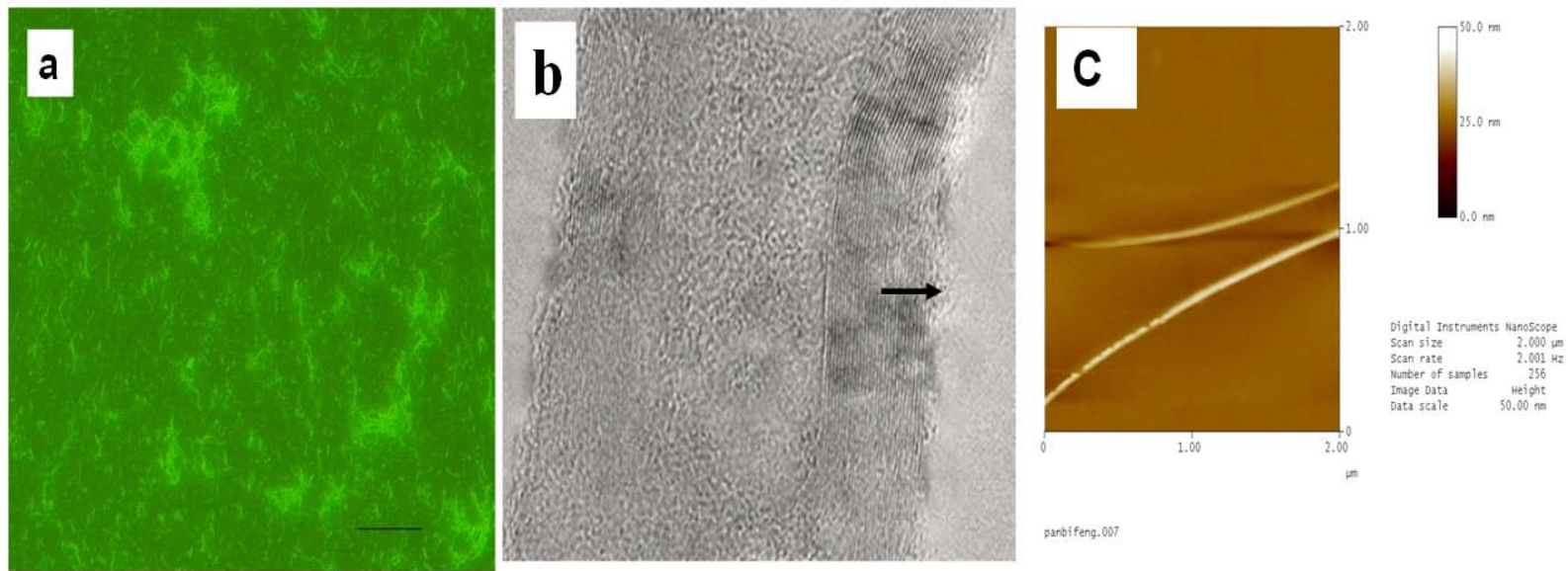

Fig. 1 Various images of dMNTs. (a) image of dendrimer-modified fluorescent multi-walled carbon nanotubes by fluorescent microscopy, bar $1 \mu$ m, (b) HR-TEM image of multi-walled carbon nanotubes (dMNTs), (c) AFM image of G5.0 dendrimer modified MNTs 
obtained in the tapping mode with standard Si/N tips.

\subsection{ES Cells' culture and MTT analysis}

ES CCE cells were cultured in RPMI 1640, containing $1 \times 10^{5} \mathrm{mU} \mathrm{mL}^{-1}$ of penicillin and $0.1 \mathrm{mg} \mathrm{mL}^{-1}$ of streptomycin supplemented with $10 \%(\mathrm{v} / \mathrm{v}) \mathrm{FCS}$, at 37 ${ }^{\circ} \mathrm{C}$ in a humidified $5 \% \mathrm{CO}_{2}$ and $95 \%$ air atmosphere. The mediums were exchanged once every 2 days. The cells were observed by contrast optical microscopy. An MTT (tetrazolium salt) assay was conducted to evaluate the effects of dMNTs on ES CCE cells. The inhibition curve of cell proliferation can be drawn $[27,28]$.

\subsection{Morphologic observation of ES cells incubated with dMNTs}

All ES cells were seeded into 6 well-chambered cover slides for $\sim 24 \mathrm{~h}$ in an RPMI 1640 cell growth medium. $40 \mu \mathrm{g} \mathrm{ml}^{-1} \mathrm{dMNTs}$ were added into the medium and co-cultured with ES cells at $37^{\circ} \mathrm{C}$ for $24 \mathrm{~h}$ in $5 \%$ $\mathrm{CO}_{2}$ atmosphere. Then the cells were fixed with $2.5 \%$ glutaraldehyde in PBS at $4^{\circ} \mathrm{C}$ for $20 \mathrm{~min}$. Finally, the cells were observed through fluorescent microscopy (Nikon 2000, Japan), and the cellular images were recorded.

\section{Results and Discussion}

\subsection{Characterization of dendrimer-functionalized multi-walled carbon nnaotubes}

As shown in Fig. 1a, synthesized fluorescent multiwalled carbon nanotubes own green fluorescent signal in

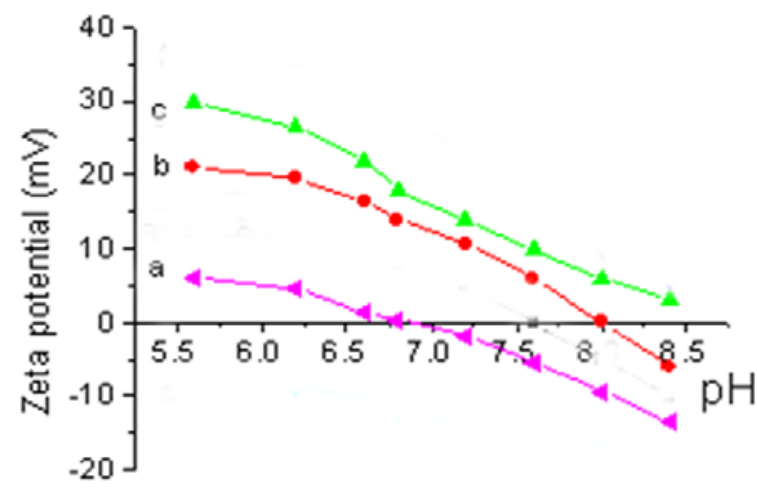

Fig. 2 Zeta potential analysis of dendrimer-FCNTs (a) FMNTs; (b) G4 dendrimer-FMNTs; (c) G5 dendrimer-FMNTs.

culture medium, similar to previous report [29]. As shown in Fig. $1 \mathrm{~b}$ and 1c, demdrimer coating layer existed on the surface of multi-walled carbon nanotubes. As shown in Fig. 2, generation5 dendrimer-functionalized fluorescent multi-walled carbon nnaotubes exhibited stronger positive charge than unmodified multi-walled carbon nanotubes. These results demonstrate that demdrimer-functionalized fluorescent carbon nanotubes were successfully synthesized.

\subsection{Effects of dMNTs on the adhesion and proliferation of ES cells}

As shown in Fig. 3, as the incubation day increased, the ES cells gradually floated, became smaller and smaller, which showed that dMNTs can decrease the adhesive ability of ES cells, may induce apoptosis of ES cells. The
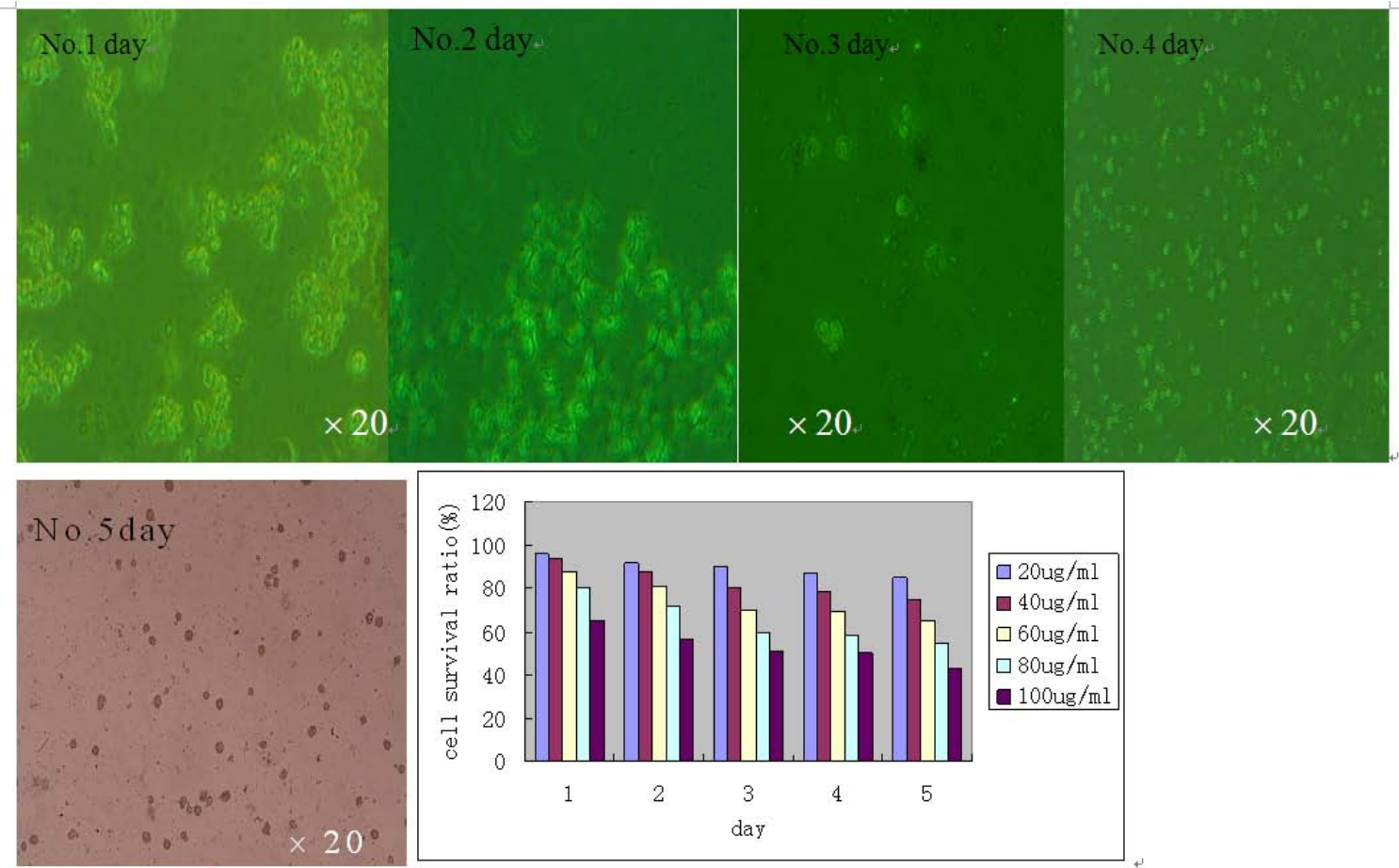

Fig. 3 Morphological changes of ES Cells with $40 \mu \mathrm{g} \mathrm{ml}^{-1}$ dMNTs for No.1 to 5 day and ES Cell survival curves incubated with different doses of dMNTs 
http://nanobe.org

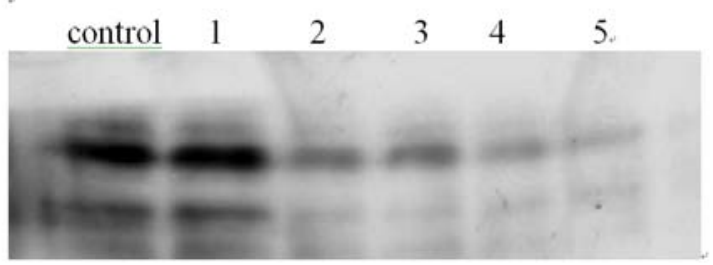

Fig. 4 Western blotting analysis of Fibronectin in ES cells with $60 \mu \mathrm{g}$ $\mathrm{ml}^{-1} \mathrm{dMNTs}$

Control: ES cells without dMNTs; No.1-5 lanes: fibronectin protein expression of ES cells incubated with $60 \mu \mathrm{g} \mathrm{ml}^{-1} \mathrm{dMNTs}$ at No.1 to No.5 day

ES cell survival curves showed that dMNTs inhibited proliferation of ES cells in dose-and time-dependent means.

As shown in Fig. 4, as the incubation day of ES cells increased, compared with the control, the expression levels of fibronectin protein in ES cells became lower and lower, which showed that ES cells' adhesive ability decreased gradually as the incubation time increased.

\subsection{Effects of dMNTs on the differentiations of ES cells}

As shown in Fig. 5(left image), fluorescent multi-walled carbon nanotubes located win ES cells, which showed that dMNTs can enter into ES cells. As shown in Fig. 5 (middle and right images), part ES cells were differentiated into long tree-branched cells. When the ES cells were incubated with $5 \mu \mathrm{g} \mathrm{ml}^{-1}$ dMNTs in medium for No.5 day, the differentiated cells could be observed, which showed that low dose of dMNTs can improve differentiation of ES cells. We also used flow cytometer to confirm the ES cells' differentiation(data not shown), showing that low dose of FCNTs can improve the differentiation of ES cells.

Although carbon nanotubes have been broadly investigated their application [30], up to date, how to deliver siRNA or protein into ES cells is still a great challengeable task. Our primary results showed that polyamidoamine dendrimer-functionalized fluorescent carbon nanotubes could enter into ES cells, may be a good nonviral gene or drug delivery system for ES cells, similar to our previous report [6,7]. Our results also showed that large dose of dMNTs $\left(>20 \mu \mathrm{g} \mathrm{ml}^{-1}\right)$ can inhibit proliferation of ES cells in dose-and timedependent means, make ES cells become smaller and smaller, part ES cells appeared apoptosis, low dose of dMNTs $\left(<5 \mu \mathrm{g} \mathrm{ml}^{-1}\right)$ can improve the differentiation of ES cells. The dMNTs maybe low toxic to ES cells within the scope of special doses. Regarding the dendrimerfunctionalized fluorescent multi-walled carbon nanotubes' toxic mechanism, some reports gave different explanation [31-33], however, we consider that it is closely associated with surface positive charges of dMNTs, which can be used to combine with genes or drugs, the dendrimer itself maybe no toxic to ES cells, which is also showed that ES cell membrane should be able to endure positive charges at some degree. However, the positive charge increases and overdue the limitation of cell membrane tolerance, which will result in cell membrane destruction, and inducing cell apoptosis or death. Under the scope of tolerance of cell membrane, positive charge of demdrimer can induce the nanoscale hole formation in the surface of ES cells by interaction with lipid protein on the surface of ES cell membrane, which will provide the rapid pathway for entrance of dendrimer -modified MCNTs into ES cells, therefore, dendrimer-modifed MCNTs own high efficiency of entering into ES cells, which also indirectly showed that dendrimer-functionalized fluorescent multi-walled carbon nanotubes may be a good gene or drug delivery system for ES cells, and have potential applications in ES cells' imaging and functional research.

\section{Conclusion}

The dendrimer-functionalized fluorescent multi-walled carbon nanotubes were successfully prepared, and exhibit dual-phase regulation to ES CCE cells, lose dose of FMCNTs can improve the proliferation and differentiation of ES cells, high dose of FCNTs can inhibit the growth of ES cells, which may be a good regulation reagent to control growth and differentiation of ES cells, and have potential applications in ES cells' imaging and functional research.
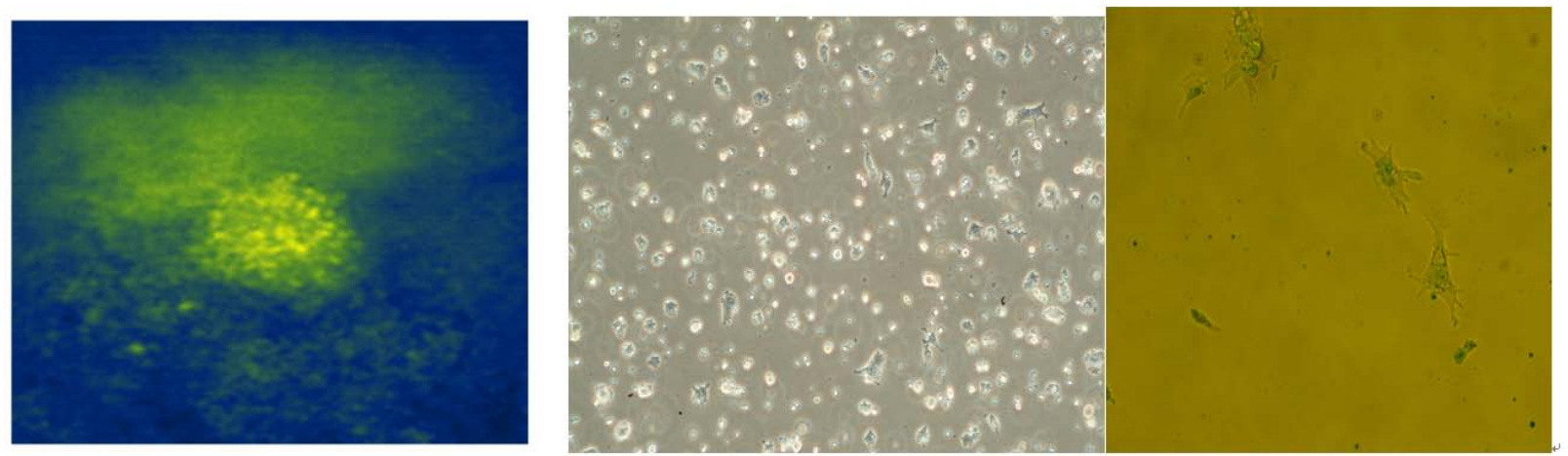

Fig. 5 Distribution of dMNTs in ES cells by fluorescent microscopy (left) and images of cells' differentiation (middle and right). Scale is $20 \mu \mathrm{m}$. 


\section{Acknowledgements}

This work was supported by the budget from Strategic Fund for Establishing the International HQs of Universities in Waseda University, and the National 973 project (2010CB933901), 863 Project (No.2007AA022004), Shanghai Pujian Plan Project (No.06PJ14049), and Shanghai Foundation of Science and Technology (No. 054119527 and 0752nm024).

\section{References}

1 .Evans M. J., Kaufman M. H.. Establishment in culture of pluripotential cells from mouse embryos. Nature 1981; 292:154-156.http://dx.d oi.org/10.1038/292154a0

2. Park IH, Lerou PH, Zhao R, Huo H, Daley GQ. Generation of human -induced pluripotent stem cells. Nature Protoc. 2008; 3(7):1180-1186. http://dx.doi.org/10.1038/nprot.2008.92

3. Nakatsuji N, Nakajima F, Tokunaga K. HLA-haplotype banking and iPS cells. Nature Biotechnol 2008; 26(7): 739-740.http://dx.doi.org/1 0.1038/nbt0708-739

4. Wang Z, Ruan J, Cui DX. Advances and prospect of nanotechnology in stem cells. Nanoscale Resarch Letters 2009;4: 593-605.

5. Cui DX. Advances and prospects on biomolecules functionalized carbon nanotubes. Journal of Nanoscience and Nanotechnology 2007; 7: 1298-1314.http://dx.doi.org/10.1166/jnn.2007.654

6. Pan BF, Cui DX, Xu P, Ozkan C, Feng G, Ozkan M, et al. Synthesis and characterization of polyamidoamine dendrimer-coated multiwalled carbon nanotubes and their application in gene delivery systems. Nanotechnology 2009; 20: 12.http://dx.doi.org/10.1088/0 957-4484/20/12/125101

7. Yuan HG, Hu SL, Huang P, Song H, Wang K, Ruan J, et al. Single Walled Carbon Nanotubes Exhibit Dual-Phase Regulation to Exposed Arabidopsis Mesophyll Cells. Nanoscale Research Letters 2011; 6:44.

8. Cui DX, Tian FR, Kong Y, Titushikin I, Gao HJ. Effects of singlewalled carbon nanotubes on the polymerase chain reaction. Nanotechnology 2004; 15: 154-157.http://dx.doi.org/10.1088/0957-4 484/15/1/030

9. Cui DX, Cengiz S, Kong Y, Gao HJ. Encapsulation of Pt-labelled DNA molecules into carbon nnaotubes. Mech. Chem. Biosyst. 2004; 1: 2: 114-119.

10.Gao HJ, Kong Y, Cui DX, Ozkan CS. Spontaneous insertion of DNA oligonucleotides into carbon nanotubes. Nano Letters 2003; 3: 471473.http://dx.doi.org/10.1021/n1025967a

11. Cui DX, Tian FR, Coyer SR, Wang JC, Pan BF, Gao F He R, Zhang YF. Effects of antisense-myc-conjugated single-walled carbon nanotubes on HL-60 cells. Journal of Nanoscience and Nanotechnology 2007; 7: 1639-1646.http://dx.doi.org/10.1166/jn n.2007.348

12.Pantarotto D., Briand J. P., Prato M., Bianco A. Translocation of bioactive peptides across cell membrane by carbon nanotubes. Chem. Commun.2004;16-17.http://dx.doi.org/10.1039/b311254c

13.Kam N.W.S., O’ Connell M., Wisdom J. A., Dai, H. Carbon nanotubes as multifunctional biological transporters and near-infrared agents for selective cancer cell destruction. Proc. Natl Acad. Sci. USA 2005; 102: 11600-11605.http://dx.doi.org/10.1073/pnas.05 02680102

14.Robinson JT, Welsher K., Tabakman SM, Sherlock SP, Wang HL, Luong R, et al. High performance Invitro near-IR $(>1 \mu \mathrm{m})$ imaging and photothermal cancer therapy with carbon nanotubes. Nano Res. 2010; 3(11):779-793.http://dx.doi.org/10.1007/s12274-010-0045-1

15.Pan BF, Cui DX, Xu P, Chen H, Liu FT, Li Q, Huang T, You XG, Shao J, Bao CC, Gao F, He R, Shu MJ, Ma YJ. Design of dendrimer modified carbon nanotubes for gene delivery. Chinese Journal of Cancer Research, 2007; 19: 1-6.http://dx.doi.org/10.1007/s11670007-0001-0

16.Pan BF, Cui DX, Gao F, He R. Growth of multi-amine terminated poly(amidoamine) dendrimerson the surface of carbon nanotubes. Nanotechnology, 2006, 17, 2483-2489.http://dx.doi.org/10.1088/0 957-4484/17/10/008

17.Li ZM, Huang P, He R, Lin J, Yang S, Zhang XJ, et al. Aptamerconjugated dendrimer-modified quantum dots for cancer cell targeting and imaging. Materials Letter 2010; 64: 375-378.

18. Lee JW, Kim BK, Kim HJ, Han SC, Shin WS, Jin SH. Convergent synthesis of symmetrical and unsymmetrical PAMAM dendrimers. Macromolecules 2006; 39: 2418-2422.http://dx.doi.org/10.1021/ma $052526 f$

19. Pan BF, Cui DX, Sheng Y, Ozkan CG, Gao F, He R, et al. Dendrimer -modified magnetic nanoparticles enhance efficiency of gene delivery system. Cancer Research, 2007; 67: 8156-8163.http://dx.do i.org/10.1158/0008-5472.CAN-06-4762

20. Li ZM, Huang P, Zhang XJ, Lin J, Yang S, Liu B, et al. RGDconjugated dendrimer-modified gold nanorods for in vivo tumor targeting and photothermal therapy. Molecular Pharmaceutics 2010; 7: 94-104.http://dx.doi.org/10.1021/mp9001415

21. MajorosIJ, Myc A, ThomasT, Mehta CB, Baker JR. PAMAM dendrimer-based multifunctional conjugate for cancer therapy: synthesis, characterization, and functionality. Biomacromolecules 200 6;7:572-579.

22. Radu DR, Lai CY, Jeftinija K, Rowe EW, Jeftinija S, LinVSY. A polyamidoamine dendrimer-capped mesoporous silica nanospherebased gene transfection reagent. J Am Chem Soc 2004; 126:1321613217.http://dx.doi.org/10.1021/ja046275m

23. Pan B, Gao F, Gu H. Dendrimer modified magnetite nanoparticles for protein immobilization. J Colloid Interface Sci 2005; 284:1-6. http://dx.doi.org/10.1016/j.jcis.2004.09.073

24.Chen DF, Wu XB, Wang JX, Han BS, Zhu P, Peng CH. Morphological observation of interaction between PAMAM dendrimer modified single walled carbon nanotubes and pancreatic cancer cells. Nano Biomed Eng 2010; 2(1): 61-66.http://dx.doi.org/1 0.5101/nbe.v2i1.p61-66

25. Xu P, Cui DX, Pan BF, Gao F, He R, Li Q, Huang T, Bao CC, Yang H. A facile strategy for covalent binding of nanoparticles onto carbon nanotubes. Applied Surface Science, 2008; 254: 5236-5240. http://dx.doi.org/10.1016/j.apsusc.2008.02.082

26. Pan BF, Cui DX, Ozkan CS, Ozkan M, Xu P, Huang T, Liu FT, Chen H, Li Q, He R, Gao F. Effects of carbon nanotubes on photoluminescence properties of quantum dots. Journal of Physical Chemistry C 2008; 112: 939-944.http://dx.doi.org/10.1021/jp068 $920 \mathrm{c}$

27. Cui D, Zhang H, Sheng J, Wang Z, Toru A, He R, et al. Effects of $\mathrm{CdSe} / \mathrm{ZnS}$ quantum dots covered multi-walled carbon nanotubes on murine embryonicstem cells Nano Biomed Eng 2010; 2(4): 236-244.

28. Cui, D., Tian, F., Ozkan, C. S., Wang, M., Gao, H. Effects of single wall carbon nanotubes on HEK293 cells. Toxicol. Lett. 2005; 155, 73-79.http://dx.doi.org/10.1016/j.toxlet.2004.08.015

29. Shi D., Wang W., Lian J., Liu G. K., Dong Z. Y., Wang L. M., et al. Luminescent Carbon Nanotubes. Adv. Mat. 2006; 18, 189.http://dx.d oi.org/10.1002/adma.200501680

30. Cui DX, Pan BF, Zhang H, Gao F, Wu R, Wang JP, He R, Asahi T. Self-Assembly of Quantum Dots and Carbon Nanotubes for Ultrasensitive DNA and Antigen Detection. Analytical Chemistry 2008; 80: 7996-8001.http://dx.doi.org/10.1021/ac800992m

31. Kam, S. W., Liu, Z., Dai, H. Carbon nanotubes as intracellular transporters for proteins and DNA: an investigation of the uptake mechanism and pathway. Angew. Chem. Int. Ed. 2006; 45: 577-581. http://dx.doi.org/10.1002/anie.200503389

32. Kostarelos K, Lacerda L., Pastorin G., Wu W., Wickowski S., Luangsivilay J., et al. Cellualr uptake of functionalized carbon nanotubes is independent of functional group and cell type. Nature Nanotechnology 2006; 2:108-113.http://dx.doi.org/10.1038/nnan o.2006.209

33. Tian FR, Cui DX, Schwarz H, Estrada GG, Kobayashi H Cytotoxicity of single-wall carbon nanotubes on human fibroblasts. Toxicology in vitro 2006; 20: 1202-1212.http://dx.doi.org/10.1016/ j.tiv.2006.03.008

Copyright:(c) 2011 D. Cui, et al. This is an open-access article distributed under the terms of the Creative Commons Attribution License, which permits unrestricted use, distribution, and reproduction in any medium, provided the original author and source are credited. 